represent the last word in all-round fastness and in tinctorial properties. Turning to textile auxiliaries, he outlined the fundamental principles involved in the modern 'soapless' detergents, the success of which led to intensive research in long-chain chemistry and the production of many new interesting products of which the best known is Velan PF for producing water-repellent finishes resistant to laundering and dry cleaning. Among other advances associated with the dyestuffs industry, Mr. Baddiley referred to the colour film, the discovery of sulphanilamide, and the synthetic polymers.

\section{Commerce and the Universities}

THE question of the suitability of existing arrangements in universities for the training of undergraduates for commercial careers was recently investigated by a sub-committee of the Association of British Chambers of Commerce. This body, having examined the subject in the light of information collected from university appointments bureaux, professional bodies, individual firms and various chambers of commerce, drew up a short "Report on the Commercial Employment of Students with Degrees in Commerce". The report estimates at less than a hundred the deliberate annual recruitment of young graduates into commerce for the purpose of ultimetely using them for the higher executive posts. These recruits are taken mainly by large concerns engaged in either manufacturing or retailing : no evidence was forthcoming of any appreciable recruitment to wholesale houses or shipping concerns. It appears that the recruitment of graduates on the business side is sporadic and exceptional and the firms which employ them make no special arrangements, such as are eommon on the industrial side, for their special training in business methods. The subcommittee considers that it would be advantageous to British commerce if a larger proportion of graduates were recruited, but that this will not be possible unless steps are taken to incorporate practical office and commercial experience in the university courses.

THE Association's Executive Council adopted the report and decided to circulate it with a view to a conference with representatives of the universities for discussion of the subject and for the devising, if possible, of a scheme of training in the operation of which the chambers of commerce would collaborate. The kind of collaboration envisaged is indicated by mention in the report of a sandwich system of six months in business alternating with six months of full-time university work, or a preliminary spell of work in business before entering a university, in which studies would be organized in two parts separated by another spell of business employment. The report has been coupled, not, perhaps, very appropriately, with the Spens Report on Secondary Education in a motion agreed to in the House of Commons on February 15 in favour of the Board of Education consulting local education authorities and others as to how far the recommendations in the reports should be carried into effect. Presumably the recommendation of the Chambers of Commerce will be taken up by the Universities Committee of ViceChancellors and Principals. In the discussion in Parliament, the Board's attitude towards commercial training in secondary schools was summed up. From eleven to sixteen years of age, geography and mathematics may well be taught so as to arouse an interest in the world of commerce, and there is a real place for commercial training on broad lines after the School Certificate; the prejudice against commerce as unworthy to rank with more academic careers should be eradicated.

\section{An Anatomist Analyses}

THE editor of the Lancet has begun the interesting experiment of throwing open his journal to selected medical men in various occupations, so that they may express unfettered thoughts upon any subject they choose, under the title "Grains and Scruples". The first series of contributions, five in number, appeared in the numbers of December 1938 "from an Anatomist". They discourse on the alleged gradual but definite degeneration of the medical student, who in former days is said to have been far older, more mature, and more responsible than his successor; upon the disappearance of the oldfashioned schoolboy bug-hunter, and other topies familiar to the teacher of long standing. But years have coloured the outlook, for there are still keen schoolboy naturalists, and while maturity and responsibility are difficult qualities to assess, the records show that the age of entry has been rising instead of falling. In the old days, students entered the universities at years of indiscretion undreamed of now, and the writer knew a surgeon-admiral who as a student, having passed all his medical examinations, put in a year on a whaler, until he should attain the legal age of qualification. That cannot happen often in these days.

BUT more profound puzzles confront the "Anatomist", and he poses the recurrent problem of the persistence in many groups of animals of primitive, generalized types. If changing environments demand the evolution of more complex animals to meet the new needs, how is it that there have survived through aeons of time, apparently completely meeting the requirements without significant structural change, basic forms upon which the higher developments of the group are founded ? As examples of these 'immature' forms which have not developed their potentialities, he gives the shark, the giant salamander, the tuatara lizard, the ostrich, and following Bolk's thesis of infantilization he would regard man as the permanent baby amongst mammals, emphasizing that lack of structural specialization which is man's saving grace. Finally he makes a reasoned plea for linking man ancestrally with the pig. But here he controverts his own premises, for while rightly stressing the need for depending upon characters not liable to environmental adaptation, he selects as major resemblances, dentition and hair-covering, length of tail and colour, than which no mammalian characters are more liable to adaptive variation. $\mathrm{He}_{\Theta}$ does not suggest 